\title{
Are insolation and sunspot activity the primary drivers of Holocene glacier fluctuations?
}

\author{
J. Koch and J. J. CLAgue \\ Department of Earth Sciences, Simon Fraser University, Burnaby, Canada; jkoch@sfu.ca
}

Recent research has documented significant, rapid fluctuations of climate throughout the Holocene (Masson et al., 2000; Bond et al., 2001; Mayewski et al., 2004; Jackson et al., 2005; Willard et al., 2005). One of the sources of proxy paleoenvironmental information that has long been used to document Holocene climate variability is alpine glacier fluctuations (e.g., Denton and Karlén, 1973). Most alpine glaciers react rapidly to changes in their mass balance and thus to changes in temperature and precipitation, and studies of past glacier fluctuations allow reconstruction of climate variability on centennial and decadal timescales.

We have compiled evidence for Holocene glacier fluctuations in western Canada and compared this data set with global data on Holocene glacier fluctuations. Our objective is to evaluate the hypothesis that Holocene alpine glacier fluctuations are driven by changes in solar irradiance.

\section{Global Holocene glacier fluctuations}

A complete reconstruction of Holocene glacier fluctuations is difficult because glacier advances in the Northern Hemisphere during the past millennium were the most extensive of the Holocene and, consequently, obliterated or obscured most of the evidence of previous advances. Furthermore, older moraines, where present, are commonly poorly dated. Perhaps the best evidence for glacier advances prior to the last millennium is found in glacier forefields deglaciated in the twentieth century. Remnants of forests in these forefields include in situ tree stumps and detrital logs and branches. Organic soils and detrital wood are also exposed in some composite lateral moraines exposed by recent glacier retreat. Highquality data on Holocene glacier fluctuations have been retrieved from many of these forefields and moraines (Luckman, 2000; Nicolussi and Patzelt 2000; Calkin et al., 2001; Osborn et al., 2001, in press; Wiles et al., 2002; Glasser et al., 2004; Koch et al., 2004, in press; Reyes and Clague, 2004; Holzhauser et al., 2005).

We have compiled published data on Holocene glacier fluctuations in western Canada and compared them to data from other temperate mountainous areas including the Patagonian Andes, European Alps, Alaska, Scandinavia, and New Zealand. The Canadian data set comprises 256 radiocarbon-dated samples, mainly from the southern and central Canadian Rocky and Coast Mountains (Luckman, 1977, 1995, 1996, 2000; Luckman et al., 1993; Smith and Desloges, 2000; Osborn et al., 2001, in press; Larocque and Smith, 2003; Koch et al., 2004, in press; Lewis and Smith, 2004; Reyes and Clague, 2004).

The most recent regional and global compilations of Holocene glacier fluctuations date to the 1970s and 1980s (Denton and Porter, 1970; Denton and Karlén, 1973; Porter, 1986; Röthlisberger, 1986; Calkin, 1988; Clapperton and Sugden, 1988; Davis, 1988; Gellatley et al. 1988; Karlén, 1988). We have augmented these data sets with new data from Alaska (Calkin et al., 2001; Wiles et al., 2002), the U.S. Pacific Northwest (Harper, 1993), the European Alps (Nicolussi and Patzelt, 2000; Hormes et al., 2001; Holzhauser et al., 2005; Joerin et al., 2006), Patagonian Andes (Wenzes, 1999; Glasser et al. 2004; Douglass et al., 2005; Koch and Kilian, 2005), Scandinavia (Winkler, 2003; Winkler et al., 2003; Shakesby et al., 2004; Bakke et al., 2005), and New Zealand (Winkler 2004). Chronological control for these studies was provided by dendrochronology, lichenometry, radiocarbon dating of fossil wood in moraines, cosmogenic surface exposure dating, proglacial lake sediments, and tephras. The augmented data sets allow us to compare Holocene glacial fluctuations in western Canada with those in other regions with greater clarity than has been possible in the past.

These records provide evidence for broadly synchronous periods of glacier advance around the world at 8600-8100, 7300-5900, 5100-4200, 4200-1900, 1900$900 \mathrm{cal} \mathrm{yr} \mathrm{BP}$, and during the past millennium (Little Ice Age) (Fig. 1). The broad age ranges of the six periods of more extensive glaciation are the result of large uncertainties introduced by calibrating radiocarbon ages. Glacier extent at the end of each of the six periods, however, was much greater than at the beginning of the following advance period. Synchronicity between regions and hemispheres indicates that climate is being forced by a single mechanism or a combination of mechanisms that is global in its effect.

\section{Forcing of global Holocene glacier fluctuations}

The global data set discussed above was used to evaluate the hypothesis of Denton and Karlén (1973) and Karlén and Kuylenstierna (1996) that Holocene alpine

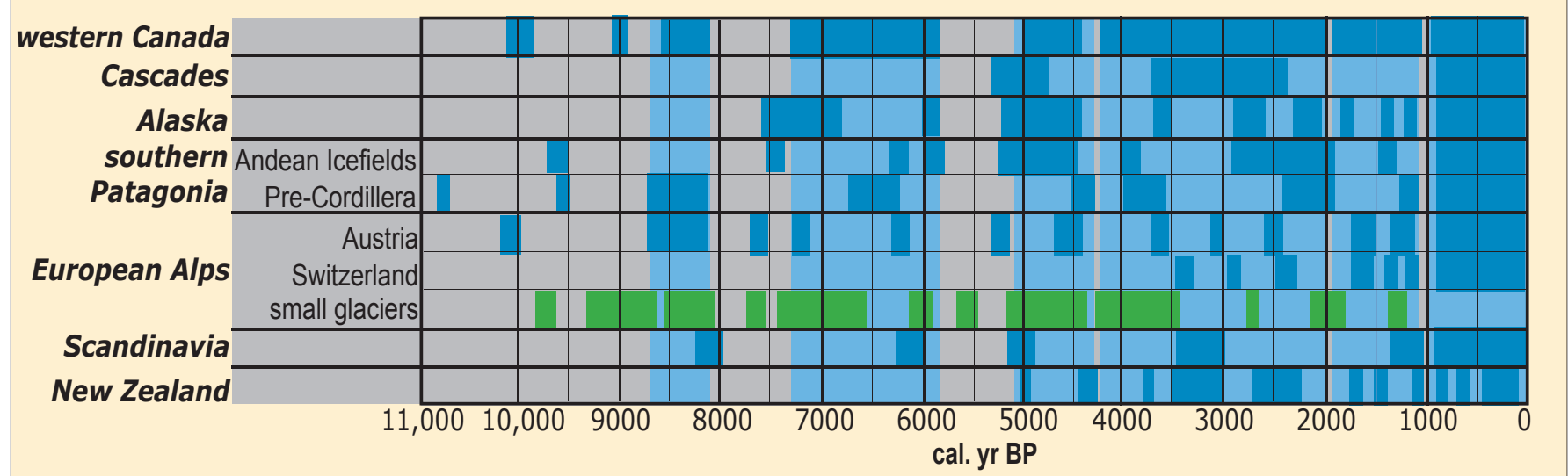

Figure 1: Timing of global glacier fluctuations during the Holocene. Horizontal blue bars indicate times of glacier advance; horizontal green bars are times when glaciers in the Swiss Alps were relatively small; vertical light blue bars are periods of glacier advance based on the global data set. 
glacier fluctuations were caused by variations in solar irradiance. Our evaluation is based on the most recent reconstruction of Holocene sunspot activity by Solanki et al. (2004). They inferred variations in solar irradiance on a decadal timescale to AD 1950 from changes in the production of atmospheric ${ }^{14} \mathrm{C}$ stored in trees.

Our analysis indicates that, on a centennial timescale, major Holocene glacier advances coincide with times of low sunspot activity (Fig. 2). It also confirms previous suggestions (Lawrence, 1950; Wiles et al., 2004; Luckman and Wilson, 2005) that sunspot activity and glacier fluctuations coincide on a decadal timescale during the past millennium (Fig. 2).

The relative extents of synchronous glacier advances in the two hemispheres, however, are different (Fig. 3). Glaciers in the Northern Hemisphere were most extensive in the late Holocene, whereas those in the Southern Hemisphere were most extensive in the early Holocene. These differences are probably due to changes in solar insolation in the two hemispheres over the course of the Holocene. During the early Holocene, insolation was high in the Northern Hemisphere and low in the Southern Hemisphere, consistent with the greater extent of glaciers in the south than in the north. In contrast, in the late Holocene, insolation was low in the Northern Hemisphere and

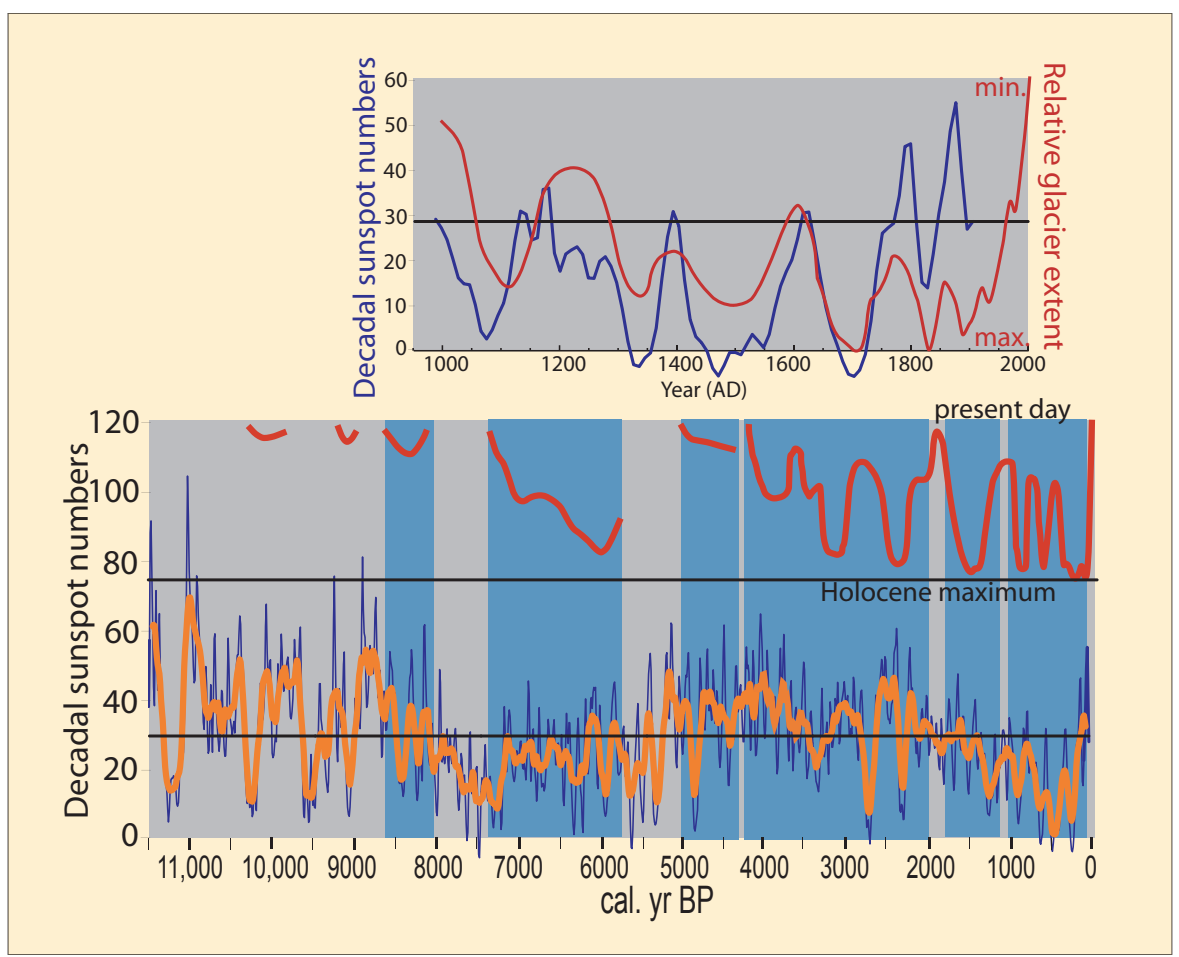

Figure 2: Glacier fluctuations in western Canada and reconstructed decadal sunspot numbers (Solanki et al., 2004) during the Holocene (bottom) and the past millennium (top). The red line represents relative glacier extent through time (top is present extent; bottom is maximum Holocene extent). The blue line shows decadal sunspot numbers, and the orange line (bottom) is an 11-point smoothed reconstruction of sunspot numbers. The blue vertical bars (bottom) indicate periods of global glacier advance. The negative reconstructed sunspot values are an artefact introduced by uncertainties in the reconstruction (Solanki et al., 2004).

past millennium. Synchronicity implies that one or more mechanisms have operated on a global scale to force climate change during the Holocene. Major glacier advances occur at times of low sunspot numbers on centennial and decadal

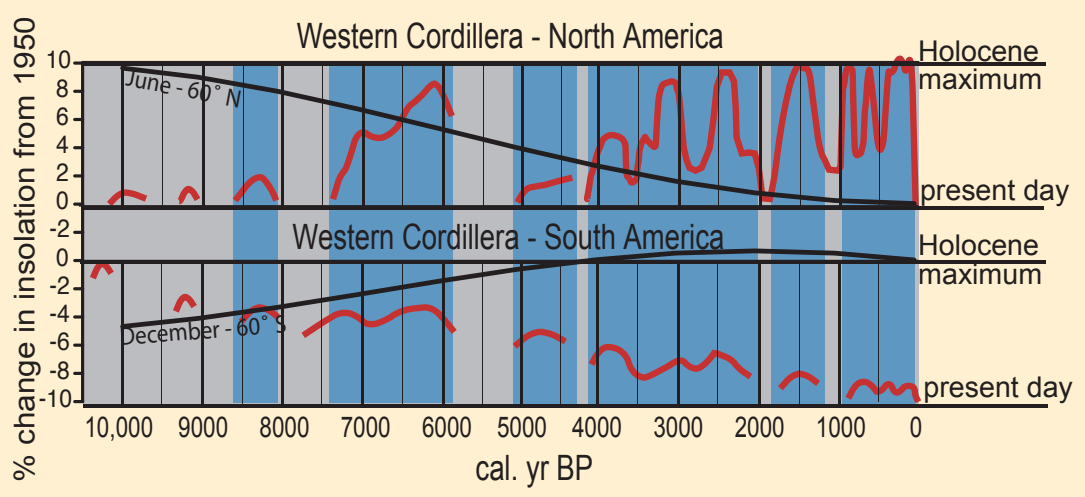

Figure 3: Patterns of Holocene glacier fluctuations in the Cordilleras of North and South America, which are considered representative of the two hemispheres, and summer insolation at $60^{\circ} \mathrm{N}$ and S after Bradley et al. (2002). The vertical blue bars indicate periods of global glacier advance.

high in the Southern Hemisphere, again consistent with the greater extent of glaciers in the north than in the south.

\section{Conclusions}

Recently published data on Holocene glacier fluctuations show that glacier advances on different continents and the two hemispheres were broadly synchronous, with major advances at 8600 8100, 7300-5900, 5100-4200, 4200-1900, 1900-900 cal. years BP, and during the timescales. Global glacier recession in the twentieth century may be partly due to high sunspot numbers, but changes in solar irradiance cannot be the sole cause of observed warming and glacier recession during the past three decades (Solanki et al., 2004). The differences in glacier extent between the Northern and Southern Hemispheres during successive Holocene advances are attributed to differences in solar insolation between the two hemispheres. Glacier advances were less extensive when solar insolation was high, that is in the early Holocene in the Northern Hemisphere, and in the late Holocene in the Southern Hemisphere.

\section{Acknowledgements}

This research was supported by a Geological Society of America grant to JK and a Natural Sciences and Engineering Research Council of Canada Discovery Grant to JC. We thank BC Parks for permission to work in Garibaldi Provincial Park and Sami Solanki for providing data on sunspot numbers.

\section{References}

Bradley, R.S.,Briffa, K.R. Cole, J.E, Hughes, M.K. and Osborn, TJ., 2002 The climate of the last millennium. In: Alverson, K.D., Bradley, R.S., and Pedersen, T.F. (Eds), Paleodimate, Global Change, and the Future, Springer, Berlin, 105-141.

Denton, G.H. and Karlén, W., 1973: Holocene climatic variations - Their pattern and possible cause, Quaternary Research, 3: 155-205.

Karlén, W. and Kuylenstierna, J., 1996: On solar forcing of Holocene climate: Evidence from Scandinavia, The Holocene, 6: 359-365.

Mayewski, P.A., Rohling, E.E., Stager, J.C., Karlén, W., Maasch, K.A., Meeker, L.D., Meyerson, E.-A., Gasse, F., van Kreveld, S., Holmgren, K., Lee-Thorp, J., Rosqvist, G., Rack, F., Staubwasser, M., Schneider, R.R. and Steig, E.J., 2004: Holocene climate variability, Quaternary Research, 62: 243-255.

Solanki, S.K., Usoskin, I.G., Kromer, B., Schüssler, M. and Beer, J., 2004: Unusual activity of the Sun during recent decades compared to the previous 11,000 years, Nature, 431: 1084-1087.

For full references please consult:

www.pages-igbp.org/products/newsletters/ref2006_3.html 